\title{
ANTI-TERRORISM FINANCING LAWS IN MALAYSIA: CURRENT TRENDS AND DEVELOPMENTS
}

\author{
Aishat Abdul-Qadir Zubair* \\ Umar A. Oseni** \\ Norhashimah Mohd. Yasin $* * *$
}

\begin{abstract}
Malaysia has continued to proactively enhance its legal framework for combating terrorism financing as a phenomenal response to the global war against terrorism. This paper revisits the provisions relating to anti-terrorism financing in the Anti-Money Laundering and Anti-Terrorism Financing Act 2001 (AMLATFA), and the recent amendment made to the Act in 2014, as well as the Penal Code of Malaysia. While this study focuses on Anti-Terrorism Laws in Malaysia, AMLATFA forms the crux of the discussion in the light of current developments in anti-terrorism legislation in Malaysia. A brief Islamic legal perspective on anti-terrorism financing is given in the light of specific provisions of AMLATFA and the Penal Code. The paper finds that Malaysia is keeping up with the global developments in Anti-Terrorism Financing laws and this has helped it to maintain a good image in the global world as a country that is ready to combat terrorism generally and terrorism financing specifically. With the emerging threats of the self-styled Islamic State in Iraq and Levant (ISIL) in Malaysia and the world at large, there is no better time than now to come up with a more comprehensive law such as the Prevention of Terrorism Act 2015 to complement existing legislations on terrorism financing.
\end{abstract}

Keywords: anti-terrorism financing, Malaysia, terrorism, Prevention of Terrorism Act 2015

Corresponding author, Ph.D. candidate, Ahmad Ibrahim Kulliyyah of Laws, International Islamic University Malaysia.

** Assistant Professor, Ahmad Ibrahim Kulliyyah of Laws, International Islamic University Malaysia.

*** Professor, Ahmad Ibrahim Kulliyyah of Laws, International Islamic University Malaysia. 


\title{
UNDANG-UNDANG PEMBIAYAAN ANTI-KEGANASAN DI MALAYSIA: HALATUJU DAN PERKEMBANGAN TERKINI
}

\begin{abstract}
ABSTRAK
Malaysia meneruskan usaha proaktif untuk meningkatkan rangkakerja undang-undang untuk membasmi pembiayaan keganasan besarbesaran sebagai tindakbalas kepada peperangan sejagat menentang keganasan. Makalah ini mengkaji peruntukan undang-undang mengenai pencegahan pembiayaan keganasan yang termaktub di dalam Akta Pencegahan Pengubahan Wang Haram dan Pencegahan Pembiayaan Keganasan 2001 (APPWHPPK) dan pindaan 2014 serta peruntukan yang terkandung di dalam Kanun Keseksaan, Walaupun kajian ini mefokuskan kepada undang-undang pencegahan keganasan di Malaysia, APPWHPPK menjadi tumpuan dan fokus utama ekoran perkembangan mutakhir mengenai isu tersebut. Perspektif Islam di dalam menangani isu pembiayaan keganasan juga dipaparkan secara ringkas menerusi peruntukan spesifik di dalam APPWHPPK dan juga Kanun Keseksaan. Kajian ini mendapati Malaysia adalah setanding dengan perkembangan global terhadap undang-undang pencegahan pembiayaan keganasan. Justeru itu, ianya membantu mengekalkan imej Malaysia yang baik di mata dunia sebagai negara yang bersiap sedia untuk membasmi keganasan amnya dan pembiayaan keganasan khasnya. Dengan tercetusnya ancaman baru oleh pihak yang mengaku sebagai penubuhan negara Islam di Iraq dan Syria (ISIS) kepada negara Malaysia dan dunia keseluruhannya, telah sampai masanya untuk dilaksanakan undang-undang yang lebih komprehensif seperti Akta Pencegahan Keganasan 2015 sebagai pelengkap kepada undang-undang pembiayaan keganasan yang sedia ada.
\end{abstract}

Kata kunci: Pencegahan pembiayaan keganasan, Malaysia, keganasan, Rang Undang-undang Pencegahan Keganasan 2015

\section{INTRODUCTION}

The increasing technological breakthroughs in the modern world and their consequent utilisation in the global financial system has improved the way people transact businesses across the world. However, this trend has not come without its associated risks that are gradually threatening 
global peace. Terrorism financing through various channels, which was not a global menace many decades ago, came into the limelight after the September 11, 2001 attack in the United States. In quick response to the attack and the growing incidences of terrorist activities across the world, the United Nations Security Council, through Resolution 1373 known as UNSCR 1373, supplemented the United Nations International Convention for the Suppression of the Financing of Terrorism 1999. This Resolution introduced a new international legal regime for combating terrorism financing and it came into force on $10^{\text {th }}$ April 2002. Malaysia acceded to the Convention on 29 May 2007; and hence, joined the global move towards combating terrorism financing. ${ }^{1}$

Malaysia enacted its consolidated law in order to take proactive measures to prevent money laundering and terrorism financing offences. Before the unfortunate September 11 incident, Malaysia had the Anti-Money Laundering Act (AMLA) but decided to extend the legal framework by also providing for anti-terrorism financing. The Malaysian Parliament passed amendments to AMLA in November 2003 to include terrorism financing as one of the predicate offences covered under the Act which is also listed in Chapter 6A of the Penal Code.

The foregoing developments led to the enactment of the Anti-Money Laundering and Anti-Terrorism Financing Act 2001 (AMLATFA) which came into force on January 15, 2002 to combat illegal financial flows. This prompt overhaul to the existing legal framework for combating money laundering in Malaysia includes terrorism financing in its general scope as recommended by the Financial Action Task Force (FATF) after the September 11 attack. $^{2}$ In AMLATFA, reporting institutions are required to promptly submit suspicious transaction reports (STR) to the financial intelligence unit (FIU) of the Central

Lavalle Roberto, "The International Convention for the Suppression of the Financing of Terrorism". Heidelberg Journal of International Law, 60, (2000): 491. "Prior to the adoption by the United Nations General Assembly, on December 9, 1999, of the International Convention for the Suppression of the Financing of Terrorism (Financing Convention or Convention), 1 the community of states had made arduous efforts, which are being pursued, to cope with international terrorism in a collective manner. This has been done through two basic modalities. The longest established one is embodied in an impressive series of complex and wide ranging multilateral treaties, most of them open to all states, that seek to cope with the phenomenon by depriving terrorists of sanctuaries and ensuring international cooperation in suppressing their activities and bringing them to justice. Each of these treaties is directed towards a specific type or area of terrorist activity".

Norhashimah Mohd Yasin, Legal Aspects of Money Laundering in Malaysia from the Common Law Perspective. (Malaysia: Lexis Nexis, 2007). 
Bank of Malaysia, popularly known as Bank Negara Malaysia (BNM). Recently there has been an amendment to the AMLATFA which is termed the Anti-Money Laundering and Anti-Terrorism Financing (Security Council Resolution) (Al-Qaida and Taliban) Amendment Order 2014. This new amendment is unique because it provides further clarity on reporting obligations.

Most laws on anti-terrorism financing are merged with anti-money laundering laws. It is admitted that the two global phenomena are interrelated and indeed often overlap in some cases, as one may be used as the conduit pipe to actualize the other; they are often confused with one another. Therefore, this article specifically focuses on antiterrorism financing but there are instances where it is inevitable to also relate the discussion to money laundering. The abuse or negative utilisation of technological advancement in the global financial system for terrorism financing is what the Malaysian Act tries to combat. This is most important as the view of some scholars is that Islamic banks are sometimes used by terrorist to finance terrorist acts. ${ }^{3}$ Nevertheless, what is obvious is that a majority of the countries of the world have similar legislations in place to combat terrorism. Hence, the first part of this article focuses on terrorism financing, its background, tracing it to the September 11 attack, the sources of terrorism financing and finally a cursory look at some of the relevant provisions of the AMLATFA. The second part of this article shall examine specifically Part VIA of AMLATFA on the Suppression of Terrorism Financing Offences and Freezing, Seizure and Forfeiture of Terrorist Property as well as the provisions contained in Chapter VIA of the Penal Code (Amendment) Act 2003 (Act A1210). The last part gives an exploratory review of the recent amendment to the Act in 2014, looking at the main aim of the amendment and its implication on the Anti-terrorism financing Laws in Malaysia. It also briefly examines the Prevention of Terrorism Act 2015 which is expected to curb the increasing threats of the Islamic State in Iraq and Levant (ISIL) in Malaysia.

\footnotetext{
3 Schneider Friedrich. "Macroeconomics: The Financial Flows of Islamic Terrorist" In Masciandaro Donato, ed. Global financial crime: Terrorism, money laundering, and off shore centres. (England: Ashgate Pub Limited, 2004). who believes the trust-based underground banking known as hawālah may have been employed by the Al-Qaeda group. This is a wrong notion of Islamic Finance. Islamic finance is merely a faithbased alternative financial system.
} 


\section{WHAT IS TERRORISM FINANCING}

Money is said to be the oxygen or lifeblood of terrorism. ${ }^{4}$ Terrorism financing is a term used for the funds and other property made available for use by the terrorists as well as in relation to the proceeds of terrorist activities. Terrorism financing is an offence which includes but is not restricted to receiving or making contributions towards terrorists funding or inviting others to do so. This will include also making a gift or a loan. It is therefore prohibited to be involved in fund raising in circumstances where the person involved intends, or had reasonable cause to suspect, that the money or other property raised may be used for purposes of terrorism.

Terrorism financing focuses on funds, which may be derived from sources which are legitimate used to commit a crime. Bank Negara Malaysia (BNM) has defined terrorism financing as:

[F]inancing of terrorism generally refers to carrying out transactions involving funds that may or may not be owned by terrorist, or that have been, or are intended to be used to assist the commission of terrorism. ${ }^{5}$

Anti-Money Laundering and Anti-Terrorism Financing Act (AMLATFA) also defines terrorism financing offences under section 3(1) as:

[A]ny offence under Section 130N, 130O, 130P or 130Q of the Penal Code Essentially, financing of terrorism includes-

(a) providing or collecting property for carrying out an act of terrorism;

(b) providing services for terrorism purpose;

(c) arranging for retention or control of terrorist property; or

(d) dealing with terrorist property.

A similar definition is provided under the Penal Code (Amendment) Act $2003^{6}$ where the offence of terrorism financing is said to mean

Salam El-Fatih A. Abdel, "War on Terror: Fantasy and Fiction Behind the Mythology of Terrorist Financing" Intellectual Discourse. (2009) 17(1), 1-23.This cliché which has now become a proverbial saying was initially expressed by the former U.S. President George W. Bush and his Secretary of State, Colin Powell in the aftermath of the September 11 attacks.

Bank Negera Malaysia, "Standard Guidelines on Anti-Money Laundering and Counter Financing of Terrorism”, Financial Intelligence Unit, BNM/RH/GL000-2, 2.

Act A1210. 
any offence under sections $130 \mathrm{~N}, 130 \mathrm{O}, 130 \mathrm{P}$ or 130Q. These sections shall further be looked into in the subsequent parts of this article. From the foregoing it can be noted that the offence of terrorism financing is meant to govern the action of third parties and only in rare cases do we have situations where terrorist themselves finance their act of terror.

\section{BACKGROUND TO TERRORISM FINANCING}

In many parts of the world terrorism has remained, for a very long time, a weapon of the weak against rulers and governments who are economically, politically and even militarily stronger. ${ }^{7}$ The act of terrorism dates back to the 70 A.D. during the Roman Empire. A group known as "Sicariis", who were known for killing the Roman occupiers of Palestine and their Jewish collaborators, perpetuated terrorist acts during that period. ${ }^{8}$ The eleventh to thirteenth century, as well as the beginning of the Middle-Ages also witnessed some form of contemporary terrorism where a small group of people waged a war or more appropriately put, campaigns of terror against the government which was the central political power and much stronger opponents. This period was characterised by the religious sects and so it was sometimes assumed that terrorism originated from religious and pseudo religious sects, who, in the name of God resorted to political violence. ${ }^{9}$ The period known as post-cold war era also witnessed the emergence of a number of groups and movements that have committed acts of terrorism in the war. Examples of such groups are the Revolutionary Armed Forces of Columbia (FARC), the Euzkadi Ta Askatasuna (ETA) and a host of others. These groups had different motives in carrying out the act of terrorism ranging from political to religious reasons and even to protecting the environment. ${ }^{10}$

However, the second half of the nineteenth century witnessed the emergence of modern-style terrorism. With the outbreak of World War II terrorism went into high flare, for example, the anti-British bombings in the United Kingdom perpetrated by the Irish Republican Army (IRA). This was small if compared to the post war era because the most powerful outburst of political violence occurred during

\footnotetext{
$7 \quad$ Briggette L. Nacos, Terrorism and Counter-terrorism: Understanding Threats and Responses in the post- 9/11 World. (Boston: Longman, 2010).

Ibid.

Ibid.

10 For example the environmental extremists like earth first and the earth liberation front carried out acts of terrorism in the name of protecting the environment.
} 
this period. This can be linked to the struggle for decolonisation and national liberation and sometimes revolutionary social change by most countries. An example of such acts of terrorism was the airline hijacking and sabotage by the Palestinian guerrillas in 1968 with the name the Popular Front for the Liberation of Palestine (PELP). ${ }^{11}$ As illustrated in Table 1 below, the year 2012 recorded an estimate of about 7,467 targets of terrorist attacks.

Table 1: Targets of Terrorist Attacks Worldwide, $2012^{12}$

\begin{tabular}{l|r}
\multicolumn{1}{c|}{ Target Type } & Number of Targets \\
\hline Private Citizens/Property & 2073 \\
Police & 1699 \\
\hline Government (General) & 971 \\
Business & 480 \\
\hline Military & 379 \\
Educational Institution & 325 \\
\hline Unknown & 285 \\
Religious Figures/Institutions & 223 \\
\hline Transportation & 221 \\
Utilities & 177 \\
\hline Terrorists or Non-state Militia & 144 \\
Government (Diplomatic) & 95 \\
\hline Journalists and Media & 84 \\
Violent Political Party & 83 \\
\hline Other & 78 \\
Telecommunication & 57 \\
\hline NGO & 44 \\
Airports \& Airlines & 20 \\
\hline Food or Water Supply & 19 \\
Tourists & 10 \\
\hline Total & $\mathbf{7 4 6 7}$
\end{tabular}

11 Briggette L. Nacos, Terrorism and Counter-terrorism.

12 U.S. Department of State, Country Report on Terrorism 2012, National Consortium for the Study of Terrorism and Responses to Terrorism: Annex of Statistical Information, May 30, (2013). 9. 
The spate of terrorist attacks has continued to rise, and the correlation between such attacks and terrorism financing is quite significant. Hence, the requirement to detect and reduce the financial flows of terrorist criminal organisations by public authorities is an absolute necessity. ${ }^{13}$ But it was only after the September 11 attack that the U.S. government and the world decided to have mechanisms in place by intensifying efforts to dry up the financial resources of terrorist organisations. ${ }^{14}$ This is the main aim of the Patriot Act of the U.S. which can be said to be a solid counter-terrorist tactic-following the money trail- because it helps to identify donors, middle persons and even recipient cells and their members. The Patriot Act deprives terrorists of their financial resources in the hopes of preventing further acts of terror. This is usually done by confiscating funds in banks within their borders and putting pressure on state supporters.

Article 2(1) of the United Nations International Convention for the Suppression of the Financing of Terrorism 1999 provides:

Any person commits an offence within the meaning of this Convention if that person by any means, directly or indirectly, unlawfully and willfully, provides or collects funds with the intention that they should be used or in the knowledge that they are to be used, in full or in part, in order to carry out:

(a) An act which constitutes an offence within the scope of and as defined in one of the treaties listed in the annex; or

(b) Any other act intended to cause death or serious bodily injury to a civilian, or to any other person not taking an active part in the hostilities in a situation of armed conflict, when the purpose of such act, by its nature or context, is to intimidate a population, or to compel a government or an international organization to do or to abstain from doing any act. ${ }^{15}$

This was the beginning of the regime of anti-terrorism law around the globe including Malaysia. In order to accede to the above, the Malaysian Parliament in November 2003 passed an amendment to the already existing AMLA to include as one of the predicate offences, the

\footnotetext{
13 Schneider Friedrich, Macroeconomics: The Financial Flows of Islamic Terrorist.

14 It is pertinent to note that such blanket drive to stamp out terrorism and close all the related financing channels, though highly commendable, has unfortunately affected some innocent charitable organisations in the Muslim world.

15 United Nations Convention for the Suppression of the Financing of Terrorism ENREF_21_ENREF_18_ENREF_14_ENREF_7
} 
offence of terrorists financing under the Act. New definitions of the offence of terrorist financing and terrorist property were incorporated as Part IVA of AMLA 2001. The amendment also provided the mechanisms to report suspicious activities and suspected terrorism financing activities, measures for the detection and prevention of terrorism financing and the freezing, seizing and forfeiture of terrorist property. The Act containing the new amendments was later renamed the Anti-Money Laundering and Anti-Terrorism Financing Act 2001 Act 613 (AMLATFA). Malaysia being the Islamic finance hub is in dire need of this Act since Muslim countries and their governments are errorneously targeted as terrorists' financiers.

Apart from AMLATFA there have been some major amendments to other legislations like the Penal Code, Criminal Procedure Code, Subordinate Courts Act 1948 and Courts of Judicature Act 1964 to accommodate the new countermeasures against terrorism financing. Some of the provisions in the Penal Code will be examined together with that of AMLATFA.

\section{SOURCES OF TERRORIST FINANCING}

Terrorists need substantial financial resources to actualise their ideology and ventilate their grievances against institutions, governments and innocent people. They require such resources to operate their training facilities, acquire weapons, and travel to perpetuate their nefarious activities. Without the necessary funds, they would not be able to execute many of their activities. ${ }^{16}$

Navias ${ }^{17}$ contends that state sponsors provide financial supportboth directly (receiving cash or drawing of legally established and funded bank accounts) and indirectly (providing housing, training camps, weapons) to terrorist groups. This suggests the involvement of some governments as sponsors of terrorist acts. Regardless of whatever criteria it might have used in its classification and whether this is agreeable to other countries across the world, the U.S. Department of State identified the governments of four countries as state sponsors of

\footnotetext{
16 This is as confessed by a terrorist agent, he stated that there are times they couldn't carry out the entire act of terror as planned due to lack of funds and will just have to carry out a bit of it. See Briggette L. Nacos, Terrorism and Counter-terrorism.

Navias M. S. "Finance Warfare as a Response to International Terrorism". In L. Freedman (Ed.), Superterrorism: Policy Response. (Malden, Massachusetts: Blackwell Publishing, 2002), 57-79.
} 
terrorism. These countries are Cuba, Iran, Sudan, and Syria. ${ }^{18}$

Some communists groups supporting leftist groups in Latin America, Europe and some other places received ample support from some governments with friendly ties to Moscow. ${ }^{19}$ Meanwhile, religiously motivated groups like the Hezbollah in Lebanon, which was created in 1982, had allegedly received financial support from the Islamic Republic of Iran which was backed by Syria due to the same anti-Israeli stance of the Hezbollah group. ${ }^{20}$ Thus in the words of Daniel Byman:

Tehran has armed, trained, inspired, organised, and otherwise supported dozens of violent groups over the years. Iran has not only backed groups in its Persian Gulf neighbourhood, but also terrorists in Lebanon, Israel, Bosnia, the Philippines and elsewhere ${ }^{21}$

This in a way suggests that governments do sponsor terrorist movements by way of financial assistance.

Nevertheless, private organisations/individuals also provide donations to terrorist groups. This is usually by way of fundraising and asking for donations as sentiments veered towards these terrorist groups who often work in their favour. People tend to pity them and have a soft spot towards their sinister aims and objectives. Individuals and organisations donate significant sums to these groups. It is particularly easy for these groups to get donations especially where they are involved not only in terrorism but also in social services and legitimate political activities as well. ${ }^{22}$

The major sources of terrorist financing are from both legitimate and illegitimate sources, and the nature of the funding sources may vary according to the type of terrorist groups or organisation. It has been discovered that terrorists also engage in legitimate businesses to fund their violent acts. Though this may be very rare but sometimes trading in books, T-shirts, posters, CD's and other items, and engaging

\footnotetext{
18 For the full report on the four states identified, see U.S. Department of State, Country Report on Terrorism 2012, 195 - 200.

19 Briggette L. Nacos, Terrorism and Counter-terrorism.

20 Ibid.

21 Daniel Byman, Deadly Connections: States That Sponsor Terrorrism. (New York: Cambridge University Press, 2005), 79.

22 Private organisations like The Defence and Aid Fund, Anti-Apartheid Movement and various other radical groupings in London; Oxfam and War on Want; Evert Vermeer organization has been said to provide fund for certain terrorist groups also the Defence and Aid Fund, collected R400 000 in 1968 - R60 000 within Britain to sponsor terrorism in the West. accessed on July 18, 2013 www.rhodesia.nl/wccterr.html.
} 
in normal import and export business such as selling and buying honey or palm oil is one of the major source of funds for these groups. This, in a way, means camouflaging their financial flow and providing legitimate revenue for their act. However in some rare cases the source of their money may come from wealthy members of the group. It is alleged that Osama bin Ladin provided funds to the Al-Qaeda group. For example, Simon ${ }^{23}$ alleged that Al-Qaeda was originally funded by Osama bin Laden's inheritance and by the profits of the commercial enterprises he established in Sudan. Also according to Zanini: ${ }^{24}$

The most notorious element of the network is Osama bin Laden, who uses his wealth and organisational skills to support and direct a multinational alliance of Islamic extremists. At the heart of this alliance is his own inner core group, known as Al-Qaeda ("The Base"), which sometimes conducts missions on its own, but more often in conjunction with other groups or elements in the alliance.

However, the illegitimate source of financing would be when terrorists get involved in criminal activities to finance their operations for example, drug trafficking and demand for ransom money from their kidnapped victims, credit card fraud, selling of forged passports, violating intellectual property rights and smuggling of persons illegally into countries. It has been alleged that they sometimes carry out operations of bank robbery to get enough funds needed to carry out a successful operation of terrorist acts. ${ }^{25}$ It is most pertinent to state here that as the source of funds for terrorism is illegal, so is the mode of transfer. This is usually not done through banks, but in most cases, through informal value transfer systems. This is done in order to escape being caught by the scrutinising nature of the finance houses and regulatory bodies that are usually in place.

It should be noted however, that no matter how effective the government is in trying to cut and freeze the accounts of these groups, they would always find a new method of obtaining funds. So while the authorities are busy studying that method in order to arrest them they are already using another method making it difficult for them to be caught and providing them with continuous funding for their terrorist activities.

23 Reeve Simon, and Ralph Lowenstein. The new jackals: Ramzi Yousef, Osama bin Laden and the future of terrorism. . (Boston, MA: Northeastern University Press, 1999).

24 Zanini Michele. "Middle Eastern Terrorism and Netwar". Studies in Conflict and Terrorism, (1999): 250.

25 This was as stated by one of the terrorists who testified for the prosecution in a case on terrorism. 


\section{SCOPE OF AMLATFA}

AMLATFA, being the amended AMLA has incorporated the offence of terrorism financing and includes sections for the freezing, seizure and forfeiture of terrorist property, measures for the detection and prevention of terrorism financing and mechanisms for reporting suspicious activities and suspected terrorism financing activities.

To begin with, the section which deals with the interpretation of Part VIA is Section 66A defines some concepts such as 'specified entity', 'terrorist act' and 'relevant regulatory or supervisory authority'. It defines 'specified entity' as:

an entity in respect of which an order under section 66B has been made or is deemed by reason of the operation of subsection $66 \mathrm{C}(2)$ to have been made, and is for the time being in force. ${ }^{26}$

Such an entity could be an actual terrorist organisation or bodies deemed to be supporting terrorism such as businesses, charities and it can be presumed that individuals could also be gazetted as such. ${ }^{27}$ Stemming from the provision of section $66 \mathrm{~B}(1)$, a question may arise that what happens if an entity that has been declared as a 'special entity' decides to change its name by separating or rejuvenating under a new title, but still bearing, in some instances a name similar to such an organisation's defunct name? An English Court of Appeal case $R v Z^{28}$ has answered this question with reference to section 11(1) of the English Terrorism Act 2000 and the purpose of section 3 of the same Act. In this case a group with the name 'Irish Republican Army' has been listed in the Schedule to the Act but some of its members later formed a new group bearing the name 'Real Irish Republican Army. Kerr, LCJ. held that:

26 Section 66B (1) of AMLATFA provides that the Minister of Home Affairs has the power to declare certain organizations as specified entities. It provides thus:

"66B. (1) Where the Minister of Home Affairs is satisfied on Information given to him by a police officer that

(a) an entity has knowingly committed, attempted to commit, participated in committing or facilitated the commission of, a terrorist act; or

(b) an entity is knowingly acting on behalf of, at the direction of, or in association with, an entity referred to in paragraph (a), the Minister of Home Affairs may, by order published in the Gazette, declare the entity to be a specified entity."

27 Norhashima Mohd, Legal Aspects of Money Laundering in Malaysia.

28 [2004] NICA 23 
We consider that the purpose of s 3(1)(b) is to ensure that organisations that grow up as a result of schism within a named terrorist organisation and operate under a broadly similar name should be proscribed.

Therefore, from this case law it is presumed that a group or organisation will not be able to escape being defined as a specified entity under AMLATFA by merely changing its name, such an entity remains subject to the Minister's order so long as the membership and objectives remain the same. ${ }^{29}$

However, such an entity may apply for the Order to be revoked within 60 days that such an order was issued by the Minister of Home Affairs. ${ }^{30}$ The Minister can either revoke the order or uphold it and notify the entity within 60 days of receiving the application. ${ }^{31}$ Section 66B (8) provides that whatever decision arrived at by the Minister of Home Affairs will be final.

Section 66B (2) also provides that the Minister of Home Affairs may, when the need arises, deliberate with such body or agency that has relevant regulatory and or supervisory authority such as $\mathrm{BNM}^{32}$ before declaring some organisations as a specified entity. Under subsection 3, it is an offence for any citizen or body corporate in Malaysia to deal with such entities in any way or manner. Contravention of the provisions of this section is punishable under subsection 4 which provides thus:

Any person who contravenes subsection (3) commits an offence and shall, on conviction, be liable to a fine not exceeding one million ringgit or to imprisonment for a term not exceeding one year or to both.

Therefore, just as it is an offence to be termed a specified entity, it is equally an offence to deal with such entities.

Such provisions could also be said to find support in a historical precedent from the events that occurred during the lifetime of Prophet Muhammad (P.B.U.H). ${ }^{33}$ There was an order against three of the companions of the prophet for their refusal to participate in the war of Tabuk. No one was allowed to mix with them, even their family

\footnotetext{
29 Norhashima Mohd, Legal Aspects of Money Laundering in Malaysia.

30 Section 66B (6) OF AMLATFA.

31 Norhashima Mohd, Legal Aspects of Money Laundering in Malaysia.

32 AMLATFA has earlier defined 'relevant regulatory or supervisory authority' to include Bank Negara Malaysia, the Securities Commission and the Labuan Offshore Financial Services Authority under its 66A.

33 P.B.U.H. means "Peace Be Upon Him", a common saying of the Muslims uttered when the name of the Prophet Muhammad is mentioned.
} 
members and they were isolated until the order was revoked after Allah revealed the verse:

(He turned in mercy also) to the three who were left behind: (they felt guilty) to such a degree that the earth seemed constrained to them, for all its spaciousness (because they are isolated), and their souls became narrow (very sad), and they are confident that there is no place for them to run away from (the wrath of) Allah, but (in repentance) to Him then He turned to them, that they might repent: Verily Allah is He Who accepts repentance, Most Merciful. ${ }^{34}$

As is seen in this verse, it is due to the repentance of the companions that God made the order to be revoked. This is at par with what the section says, in that an application for revocation of the order may be granted if the Minister is satisfied with it.

Under subsection (10) of section 66B the power of the Minister extends from making orders for the freezing of properties to making exceptions with regards to funds for basic or extraordinary expenses. Nevertheless, even orders for the freezing of properties need to be made with caution. For example the application for forfeiture was dismissed by Dato' Hj Ghazali Bin Hj Cha J. in Public Prosecutor v Thong Kian Oon \& $4 \mathrm{Ors}^{35}$. The court held that:

Based on the evidence adduced by the learned DPP, I am of the opinion that the evidence adduced is insufficient to satisfy me that the properties are the subject matter of or was used in the commission of an offence under sub-section 4(1) of the Act [AMLATFA]. As such the application for the forfeiture order against all the Respondents is dismissed.

In this case the main issue was whether there could be an automatic resort to section 56 of the Act $^{36}$ merely on mere suspicion of the police officers in the absence of any credible evidence to support the allegations. The court held that section 56 of the Act requires proper proof of the relevant facts by means of admissible evidence.

Freezing and forfeiture of property also applies under Islamic law especially with regards to those who hold public offices. Looking at the principle of trust (amānah) enshrined in the Islamic law, particularly in

\footnotetext{
Qur'an 9: 118.

[2012]MLJ 637.

This section provides that a High Court Judge shall make an order for the forfeiture if the Judge is satisfied on a balance of probabilities that the property concerned is the subject matters of an offence referred in the second schedule.
} 
the area of public law there is historical precedent worth mentioning. The second caliph of Islam, Umar bin al-Khattab was known for holding his officers accountable for whatever properties they had before he appoints them. ${ }^{37}$

Section 66C provides for orders with regards to giving effect to resolutions of the Security Council. This section is exactly the same as section 66B, except that the United Nations Security Council's resolution regarding a specified entity will be gazetted in Malaysia.

Section 66D empowers the Minister to obtain information about property owned by terrorists or that which is controlled by or on behalf of any organisation declared as specified entity. Its subsection (3) provides for mechanisms for reporting suspicious activities and suspected terrorism financing activities and mandates the regulatory or supervisory authority, for example, BNM to give such reports. ${ }^{38}$

Further down, subsection (5) makes it an offence to decline to do so. Also, under subsection (6), the section is to have effect regardless of any term of confidentiality or regulation with regards to the disclosure of information imposed by any written law.

Section 66E directs and guides the Government on how to discharge its international obligations. It allows a supervisory authority to issue guidelines when there is a new UN Security Council decision. These guidelines will overrule any law or contract, and so immunity is given. It is an offence to disclose any guidelines given as they are secret and disclosure will result in a fine of RM1 million. It further provides that the supervisory authority must report to both the Home Minister and Finance Minister every six months on any action it has taken under this section.

Section $66 \mathrm{~F}$ concludes the Part by providing that all orders made with the aim of implementing measures of counter-terrorism under the Exchange Control Act 1953 and the Labuan Offshore Financial Services Authority Act 1996 shall remain in force. The implication of this is that actions taken in relation to the orders will still be seen as valid under the law.

\footnotetext{
Therefore at a specified time usually when the time for hajj is drawing closer, there would be an account by all the officers appointed by him of their personal wealth and if he discovers any amount being over what they had before, it will be forfeited and remitted to the Public Treasury (Bayt al-Māl) of the state that the officer governs, see Sallabi, 2008.

38 Section 66D (3) provides: "The relevant regulatory or supervisory authority shall immediately report to the Minister of Home Affairs if any person or class of persons under their regulation or supervision is found to be in possession or control of terrorist property or property owned or controlled by or on behalf of any specified entity."
} 
The above represents the major sections relevant to the offence of terrorism financing as provided under Part VIA of AMLATFA. However, although Part VIA of the Act has been introduced since 2003, it has not been tested before the courts in Malaysia and it remains to be seen how effective it will be.

\section{CHAPTER VIA OF THE PENAL CODE}

Chapter VIA of the Malaysian Penal Code is a new chapter that was incorporated into the code to act as a counter measure against the act of terrorism and terrorism financing and also to serve as a supplement to the AMLATFA. The main aim of the chapter is to suppress the act of terrorism and support for it as well criminalise the act of financing terrorism. Section 130B of the Penal Code provides the interpretation of certain terms in relation to the chapter, which includes entity, terrorism financing offence, terrorist, terrorist entity and terrorist property. The punishment for one who commits any act of terror and what will suffice as evidence of facts in any criminal proceedings, are provided for under section 130C. Section 130E makes it an offence to recruit persons who are members of terrorist groups or participate in any terrorist acts.

The remaining sections may be classified into two major parts, those that deal with the terrorist property and those that deal with aiding and abetting the offence. It is quite interesting to note that the offence of terrorism financing is not only restricted to committing the act of terror alone but extends to dealing with terrorist property. This is evident from the provisions of sections 130N, 130O, 130P and 130Q of the Penal Code which are specifically defined as 'terrorism financing offences'. ${ }^{39}$ Section $130 \mathrm{~N}$ provides the punishment for whoever provides or collects property for terrorist acts. Punishment for whoever arranges for retention or controls terrorist property, deals with the said property and intentionally omits to give information about terrorist property is provided for under sections 130P, 139Q and 130R of the Penal Code respectively.

From the Islamic legal perspective, there are a number of prohibitions that do not only apply to those who commit the sin itself but to all those who have anything to do with it, however remote it is. For example, the prohibition of alcohol in Islam extends to eight categories of people as is seen in the evidence of one of the sayings of the Prophet:

39 Norhashima Mohd, Legal Aspects of Money Laundering in Malaysia. 
Allah curses all intoxicants (alcoholic beverages); (He also curses) the one who drinks it and the one who serves it, the one who sells it and the one who buys it, the one who makes it and the one who asks that it be made for him, the one who delivers it and the one to whom it is delivered. ${ }^{40}$

Another example is seen where the Prophet cursed the person who consumes rib $\bar{a}$ (interest or usury) and all his accomplices. Abdullah bin Mas'ud narrated that his father reported:

The Messenger of Allah cursed the one who consumes ribā, the one who pays it, the one who witnesses it, and the one who records it. ${ }^{41}$

From the above Prophetic sayings, it is crystal clear that Islamic law does not condone having anything to do with alcoholic drink as well as paying, witnessing and recording the transaction involving rib $\bar{a}$ just as the Penal Code prohibits any dealing with terrorist property or persons.

Section 130T of the Penal Code which is the last section of the chapter, provides for the offences by body corporate; it extends the liability of the offence provided under the above mentioned sections to the management of the body corporate found to have committed the said offences. ${ }^{42}$

For the parts that deal with aiding and abetting the offence of terrorism, a cursory look at sections 130D, 130F, 130G, 130H, 130I, $130 \mathrm{~J}, 130 \mathrm{~K}, 130 \mathrm{~L}, 130 \mathrm{M}$ and $130 \mathrm{~S}$ of the Penal Code suggests that the drafters of the code had in mind third parties who may want to escape being punished under the offence of terrorism. This is why criminal conspiracy and any act of commission and or omission in relation to the offence of terrorism are punishable under theses sections.

However, before anyone can be convicted for any of these offences, the two important elements of 'actual knowledge' and 'intention' must be present and proven beyond reasonable doubt. In an Indian Supreme Court case of People's Union for Civil Liberties \& Anor. v Union of India ${ }^{43}$ the main issue for determination was whether offences of terrorism require mens rea. The learned Attorney General's argument on the validity of section 3(3) was not accepted by Rajendra Babu J who held thus:

40 Abu Dawud, S. B. Sunan Abu Dawud. (A. T. Za'i, Ed., \& N. al-Khattab, Trans.) (Riyadh: Darussalam, 2008).Book 25, Chapter 2, Hadith No. 3674.

41 Ibid. Book 22, Chapter 4, Hadith No. 3333.

42 These are offences under section 130N, 130O, 130P and 130Q.

43 [2005] 1 LRC 115. 
Therefore, the definition of 'abets' as appears in the IPC [Indian Penal Code] will apply in a case under POTA (Prevention of Terrorism Act). In order to bring a person abetting the commission of an offence, under the provisions of the IPC it is necessary to prove that such person has been connected with those steps of transactions that are criminal. 'Mens-rea' element is sine qua non for offences under the IPC. ${ }^{44}$

The implication of the above judgement is that an offence provided under 130D, 130F, 130G, 130H, 130I, 130J, 130K, 130L, 130M and 130S of the Malaysian Penal Code would be punishable only if it was done with intent. Therefore, a person could not be said to have committed any of the offences under these sections if he did not have an intention or design to further the activities of a terrorist organisation.

It is equally not enough to only suspect that the offences under these sections have been committed; there must be real supporting evidence before an application of this nature will succeed in a court of law. In fact unnecessary suspicion may be a good cause of action for libel in Court as was seen in the case of Al Rajhi Banking and Investment Corporation $v$ Wall Street Journal Europe SPRL $L^{45}$ where an application to plead justification was not permitted. The Claimant brought an action before the English court over the publication on 6 February 2002 of an article in the Wall Street Journal Europe by the Defendant Corporation. It was published on the front page of the journal, under the headline 'Saudi Officials Monitor Certain Bank Accounts: Focus is on those with potential Terrorist Ties' and was continued on page 4 under the heading 'Certain Saudi Bank Accounts Are Being Closely monitored'.

Thus issues involving offences of terrorism and terrorism financing need to be handled with the greatest care and the provisions of the relevant laws should be taken into cognisance by all those involved.

In summation, just as AMLATFA provides for countermeasures against the act of terrorism and its financers, the Penal Code in a bid to supplement the above provisions, has also made adequate provision for criminalising the offence.

$44 \quad$ Paragraph 2 (i) lines 1-5

45 [2003] All ER (D) 148 (June). 


\section{RECENT DEVELOPMENTS ON THE ANTI-TERRORISM LAW}

In 2014 there was an amendment to the Anti-Terrorism Financing Act (AMLATFA) which is known as the Anti-Money Laundering and Anti-Terrorism Financing (Security Council Resolution) (Al Qaida and Taliban) Amendment Order 2014. The amendment was made by the Minister pursuant to the powers under Sections 66C and 66D which amends the one made in 2011 (P.U.CA) 402/2011) that is known as the "Principal Order". This new amendment contains specified entities listed in UN websites. The amendment is to ensure that the Act remains relevant and effective in combating money laundering and terrorism financing threats. It also provides further clarity on reporting obligations. This will by implication ensure effective reporting by the authorities concerned of suspected terrorism financing activities.

More recently, there was a move to specifically enact a new antiterrorism law, which generally includes, anti-terrorism financing measures to stem the growing tide of terrorism financing involving Malaysians who are being lured to join the Islamic State of Iraq and the Levant (ISIL). The new law is the Prevention of Terrorism Act (2015) otherwise known as POTA. According to the Long Title of the new law, it provides for the prevention of the commission or support of terrorist acts involving listed terrorist organisations in a foreign country or any part of a foreign country and for the control of persons engaged in such acts and for related matters. The need for this new law is heightened by the increasing spate of Malaysians travelling abroad to join the ISIL militants. Some of these militants are locally sponsored by people who reside in Malaysia. This has raised a lot of concerns on the security of the country since such deliberate acts are prejudicial to the safety of Malaysian citizens as well.

It is pertinent to observe that POTA was enacted as a result of the Resolution of the United Nations Security Council passed on 24 September2014(SCR 2178), which addressed the threats to international peace and security caused, by the acts of terrorists. Paragraph 6 of the Resolution clearly emphasises that "all member states shall ensure that any person who participates in the financing, planning, preparation or perpetration of terrorist acts or in supporting terrorist acts is brought to justice, and decides that all States shall ensure that their domestic laws and regulations establish serious criminal offenses sufficient to provide the ability to prosecute and to penalise in a manner duly reflecting the seriousness of the offense: 
(a) their nationals who travel or attempt to travel to a State other than their States of residence or nationality, and other individuals who travel or attempt to travel from their territories to a State other than their States of residence or nationality, for the purpose of the perpetration, planning, or preparation of, or participation in, terrorist acts, or the providing or receiving of terrorist training;

(b) the wilful provision or collection, by any means, directly or indirectly, of funds by their nationals or in their territories with the intention that the funds should be used, or in the knowledge that they are to be used, in order to finance the travel of individuals who travel to a State other than their States of residence or nationality for the purpose of the perpetration, planning, or preparation of, or participation in, terrorist acts or the providing or receiving of terrorist training; and,

(c) the wilful organization, or other facilitation, including acts of recruitment, by their nationals or in their territories, of the travel of individuals who travel to a State other than their States of residence or nationality for the purpose of the perpetration, planning, or preparation of, or participation in, terrorist acts or the providing or receiving of terrorist training.

From the above provisions of the UN Resolution and the eventual enactment of POTA in Malaysia, the law of anti-terrorism financing seems to be keeping pace with the increasing rate and multi-dimnesional nature of terrorism financing. Nevertheless, but expectedly, some human rights activists and human rights organisations, including the International Commission of Jurists, have criticised some provisions in POTA which allow for detention without trial. ${ }^{46}$ One would definitley agree that it is a great challenge to balance the needs to protect the state and ensure safety of the country with the requirements of international human rights law. The debate between national security and civil liberties has been ongoing since the second half of the 20th century. ${ }^{47}$ Similar restrictions on civil liberties have been experienced in the United States and some other developed countries. The logic behind

\footnotetext{
46 "ICJ condemns Prevention of Terrorism Act", FMT, accessed March 31,2015, http://www.freemalaysiatoday.com/category/nation/2015/03/31/icj-condemnsprevention-of-terrorism-act/

47 Stone Geoffrey R. "National security v. civil liberties." California Law Review (2007): 2203-2212.
} 
such restrictions is: "in order to foil the terrorist plot, the adminsitration must enact antiterrorist measures that ensure greater governmental control of information, fewer procedural protections for people linked to terrorism (as either susupects or material witnesses), and enhanced government surveillance. $"{ }^{48}$ Policy critics have continued to lament these perceived civil liberty encroachment.

\section{CONCLUSION}

The security challenges across the world, and in Malaysia in particular, require adequate laws to counter the increasing spate of terrorist acts and related issues such as terrorism financing. This paper has examined Part VIA of AMLATFA and the recent amendment made to it in 2014 as well as the chapter VIA of the Malaysian Penal Code by looking at the issue of terrorism financing, its meaning and background. It has been shown that Malaysia is ever proactive in keeping up with developments in the Anti-Terrorism Financing laws globally as it keeps its laws up to date with the trend globally. The recent amendment and proactive legislative interventions is an affirmation to such commitment and helps it to maintain its good image as one of those few Muslim countries fiercely combatting terrorism as well as seriously curbing financing of terrorist activities. This therefore serves as an affirmation that Muslims are neither terrorists nor supporters of terrorism.

Baker Nancy V. "National security versus civil liberties." Presidential Studies Quarterly 33, no. 3 (2003): 549. 
